\title{
Roadkills of Vertebrates in Venezuela
}

\author{
Jan Pinowski \\ Centre of Ecological Research, Polish Academy of Sciences Dziekanów Lesny, 05-092 Lomianki, Poland. \\ E-mail: j.pinowski@wp.pl
}

\begin{abstract}
This paper presents an analysis of vertebrate roadkills in five different habitats of tropical South America. Observations of vertebrate roadkills were conducted in 1978, on a $572 \mathrm{~km}$ road between Caracas and Mantecal / Apure in Venezuela, during the rainy season (June-October). During five passages on this route, which includes five distinct habitats, 79 vertebrate carcasses - mammals and reptiles - were found. If we assume that the carcasses remain for two days on the road, vehicles can be expected to strike 350 spectacled caimans Caiman crocodilus Linnaeus, 1758 (Alligatoridae) during the rainy season alone. Similar calculations for other species yield 313 snakes and lizards, 294 opossums Didelphis marsupialis Linnaeus, 1758 (Didelphidae), 220 crab-eating foxes Cerdocyon thous (Linnaeus, 1776) (Canidae), 129 tamanduas Tamandua tetradactyla (Linnaeus, 1758) (Myrmecophagidae), 55 capybaras Hydrochaerus hydrochaeris (Linnaeus, 1766) (Hydrochaeridae) and 37 eastern cottontails Sylvilagus floridanus Allen, 1890 (Leporidae). Numerous papers have been published on vertebrates killed by vehicles on roads in Europe, North America, and Australia, and several papers are available regarding vertebrate roadkills in Africa and Asia. From South America there are several papers on vertebrates, birds, and mammals, whereas from Venezuela only one and it deals with iguanas (Iguana iguana Linnaeus, 1758, Iguanidae). KEY WORDS. Mammals, mortality, reptiles.
\end{abstract}

RESUMO. Vertebrados mortos em estradas na Venezuela. Este trabalho apresenta uma análise de vertebrados mortos em estrada em cinco habitats tropicais diferentes na América do Sul. As observações dos vertebrados mortos em estrada foram feitas em 1978, a $572 \mathrm{~km}$ da rodovia entre Caracas e Mantecal/ Apure na Venezuela, durante a estação das chuvas (junho-outubro). Durante cinco passagens nesta rota, a qual inclui cinco habitats diferentes, foram encontradas 79 carcaças de vertebrados - répteis e mamíferos. Assumindo que as carcaças permaneçam por dois dias na estrada, é esperado que veículos matem 350 crocodilos Caiman crocodilus Linnaeus, 1758 (Alligatoridae), durante a estação das chuvas. Cálculos similares foram feitos para outras 313 espécies de cobras e lagartos, 294 gambás Didelphis marsupialis Linnaeus, 1758 (Didelphidae), 220 raposas Cerdocyon thous (Linnaeus, 1776) (Canidae), 129 tamanduás Tamanduá tetradactyla (Linnaeus, 1766) (Myrmecophagidae), 55 capivaras Hydrochaerus hydrochaeris (Linnaeus, 1766) (Hydrochaeridae) e 37 lebres Sylvilagus floridanus Allen, 1890 (Leporidae). Numerosos trabalhos têm sido publicados sobre vertebrados mortos por veículos em estradas da Europa, América do Norte e Austrália e vários trabalhos têm sido referências úteis sobre vertebrados mortos em estradas na África e Ásia. Da América do Sul existem vários trabalhos com vertebrados, pássaros e mamíferos, sendo que da Venezuela existe apenas um que tenha tratado de iguanas (Iguana iguana Linnaeus, 1758, Iguanidae).

PALAVRAS CHAVE. Mamíferos, mortalidade, répteis.

Vertebrate roadkills were observed during the rainy season (June-October) during five passages along the $572 \mathrm{~km}$ road between Caracas and Mantecal/Apure in Venezuela, a total distance of $2860 \mathrm{~km}$. Five dominant landscape types were identified along this road: 1) the Coastal Cordillera area, which includes crop fields, woods, dry savannah, and settlements; 2) non-flooded llanos with clumps of trees and palms and small bodies of water; 3 ) artificially watered rice plantations; 4) gallery forest along the river Apure, with a few crop fields; and 5) flooded llanos, largely drained, with many embankments and storage reservoirs. The gallery forest yielded 30 carcasses, the largest number. The greatest number of carcasses were noted in October, at the end of the rainy season.

Since data on animals killed on roads by passing vehicles began to be published long ago (Stoner 1925, 1935, КNOBLoch 1939, Sprague 1939, Dickerson 1939, and others), a voluminous literature has accumulated on this issue, mostly concerning Europe, North America, and Australia, summarized by BENNET 1991, Forman 1995, Forman \& Alexander 1998, Trombulak \& Frissell 2000. A few papers concern Asia (Dhindsa et al. 1988, 
Irisov 1990, TAKeuchi \& Kogamezawa 1994, Berezovikov 1995) and Africa (Broekhuysen 1965, Siegrried 1965, 1966, LeVIs 1989, Drews 1995, JACKSON 2002). In regard to South America, however, we are aware of only several papers on vertebrates from Brasil (RIBeIRo \& MonchISKI 1998, CÂNDIDO-JR. et al. 2002, FISHER 2002) and from Argentina (MonTANelLI in CÂNDIDO-JR. et al. 2002), on birds (NovelLi et al. 1988, BeNCKE \& BeNCKE 1999) and mammals (Vieira 1996, Valladares-Padua et al. 1995) from Brazil, and on pacarana Dinomys branickii Peters 1873, Dinomyidae from Bolivia (GotTenker et al. 2001). From Venezuela we know only one paper on iguana (Iguana iguana Linnaeus, 1758, Iguanidae) roadkills (RodDA 1990).

\section{MATERIAL AND METHODS}

\section{Study area}

Observations of vertebrate roadkills were conducted on the $572 \mathrm{~km}$ Caracas-Mantecal (Venezuela) road during five passages, in June, August, and October of 1978. Five sections of this road were distinguished that differ in the dominant landscape type: Section 1. Caracas-Ortiz, 133 km, through Cua, San Sebastian, and San Juan de los Morros. This section passes through the area of the Coastal Cordillera. The landscape is dominated by crop fields, woods, dry savannah, and settlements. Section 2. Ortiz-Calabozo, $88 \mathrm{~km}$. The landscape of this area consists of non-flooded Ilanos with clumps of trees and palms, and small bodies of water. Section 3. CalabozoCamaguan, $92 \mathrm{~km}$. This section of the route crosses artificially watered rice plantations. Section 4. Camaguan-San Fernando de Apure-Achaguas, $131 \mathrm{~km}$. The landscape of this section mainly consists of a gallery forest al ong the river Apure and its old beds, with a few crop fields. Section 5. Achaguas-M antecal, $128 \mathrm{~km}$. This section crosses flooded Ilanos in the rainy season, largely drained, with many embankments. Storage reservoirs typically cover an area of 5000 ha (Fig. 1).

We do not know the precise intensity of vehicle traffic on the road sections where the observations were made. In this part of Venezuela almost all transportation is by automobile, hence it may be assumed that traffic intensity is roughly proportional to population density. In 1977, the population density was 130.7 inhabitants $/ \mathrm{km}^{2}$ in the administrative district of Miranda (without Caracas), a part of section 1 (CaracasSan Sebastian), 15.1 in the district of Guarino (San SebastianSan Fernando de Apure, that is, in the remaining part of section 1 , sections 2 and 3 , and the beginning of section 4 , and merely 2.5 in the district of Apure (the remaining part of section 4 and section 5, San Fernando de Apure-Mantecal) (MARRERo 1978). These figures pertain to the total areas of these districts. Population density was likely to be higher in close vicinity to the road, especially in Apure, where this was the only road with a hard surface between San Fernando and Mantecal. It can thus be assumed that the intensity of traffic declined as the distance from Caracas increased, and that traffic was ten times greater in section 1 than in section 5 .

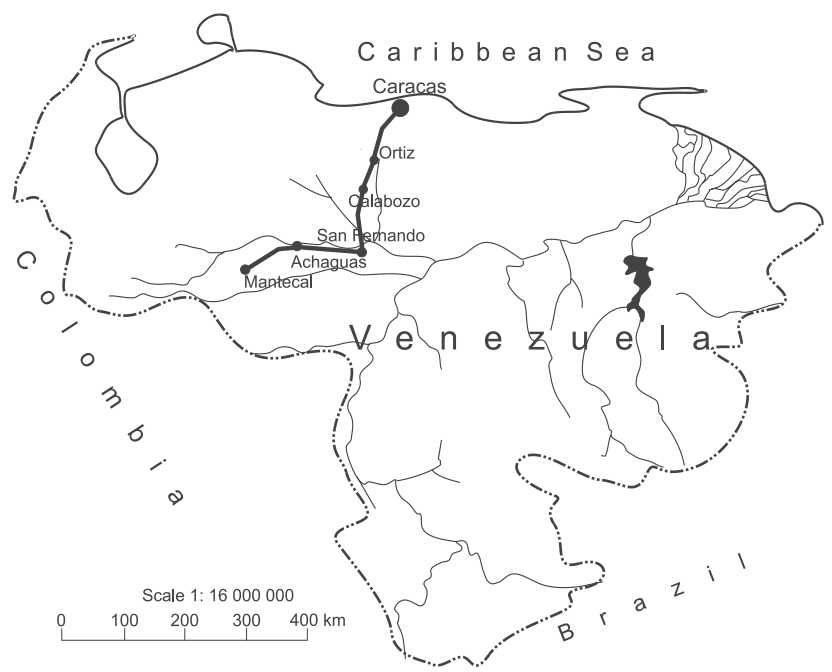

Figure 1. Map of the Caracas-Mantecal route.

\section{Methods}

Observations were conducted during passages on 26June, 19 and 24 August, and 1 and 6 October of 1978. Passages on 26 June, 19 August, and 1 October were from Caracas to M antecal, and passages on 24 August and 6 October were in the opposite direction. One passage with stops on the way took about 11 hours; trips were made during the day, between 7:00 and 18:00. A Toyota pick-up truck was used at a speed of $70-80 \mathrm{~km} / \mathrm{h}$ in flat areas (Ortiz-M antecal) and $60-70 \mathrm{~km} / \mathrm{h}$ in the Coastal Cordillera. Observations were made during the rainy season, with several showers on 1 October. The same person made observations during all passages. The observer took notes of all vertebrates more than $30 \mathrm{~cm}$ long killed on the road. Smaller individuals were not recorded as it was easy to overlook them, thus numerical data would not be reliable. Consequently, the present analysis does not involve small species of mammals, birds, reptiles, and amphibians. The place where each carcass was seen also was noted. We did not stop at the carcasses. All caimans and mammals were identified to species, but with a few exceptions. Snakes and lizards were not identified to species. Five days elapsed between each passage from Caracas to Mantecal and the return trip. Scavengers have been observed to remove killed animals within a few hours; thus, the same carcasses could not have been counted a second time during return passages. RodDA (1990), who studied iguanas in the same region, stated that "repeated observations of not manipulated roadkills indicated that scavengers removed most carcasses with in a few hours, with larger carcasses (adult iguanas) remaining longer than hatchlings". It is thus virtually impossible that a carcass would remain on the road for five days, and even more impossible for a carcass to remain during the weeks between successive passages. The road was permanently patrolled by numerous black vultures (Coragyps atratus Bechstein, 1793, Cathar- 
tidae), by a little less numerous turkey vultures (C athartes aura Linnaeus, 1758, Cathartidae), and rarely by theyellow-headed caracaras (Milvago chimachima Vieillot, 1816, Falconidae). Occasionally, several ten vultures scavenged a larger carcass (SPRUNT 1937, W allace \& Temple 1987, Coleman \& Fraser 1989). Tropical rains quickly wash the remains of carcasses from the road.

\section{RESU LTS}

Numerical observations of carcasses exceeding $30 \mathrm{~cm}$ long during five passages on the Caracas-M antecal route resulted in a total of 79 vertebrate carcasses (mammals and reptiles) along the $2860 \mathrm{~km}$-way (that is, $5 \times 572 \mathrm{~km}$ ). The largest number, 30 carcasses, were found in the gallery forest (section 4), followed by 19 carcasses in the non-flooded Ilanos (section 2), 17 carcasses in rice plantations (section 3), nine carcasses in the flooded Ilanos (section 5), and only four carcasses (opossums) in the Coastal Cordillera (section 1) (Tab. I). The greatest num- ber of carcasses were noted at the end of the rainy season in October, especially on October 1, when tropical showers occurred several times (Tab. II).

We noted 19 carcasses of spectacled caimans, Caiman crocodilus Linnaeus, 1758 (Alligatoridae), most of them (10) in the gallery forest section (Tab. I). The carcasses were dominated by individuals up to $1 \mathrm{~m}$ long (Tab. III). The greatest number of snake carcasses, seven out of 17 , was noted also in the section of roadway crossing gallery forests (Tab. I). Individuals that differed in length were found with similar frequency (Tab. III). Mammal carcasses were dominated by opossums, Didelphis marsupialis Linnaeus, 1758 (Didel phidae). Most of these, 10 out of 16, were recorded in the gallery forest (Tab. I). The greatest number of killed crab-eating foxes, Cerdocyon thous (Linnaeus, 1776) (Canidae), six out of 12 , were noted in the non-flooded Ilanos (Tab. I). Other species of mammals were occasionally found (Tab. I).

Table I. Vertebrate roadkills in various habitats of Venezuela.

\begin{tabular}{|c|c|c|c|c|c|c|}
\hline \multirow{2}{*}{ Animal Species } & \multicolumn{5}{|c|}{ Habitat type } & \multirow{2}{*}{ Total } \\
\hline & Coastal cordillera & Non-flooded Ilanos & Rice fields & Gallery forest & Flooded Ilanos & \\
\hline Caiman crocodilus & 0 & 4 & 4 & 10 & 1 & 19 \\
\hline Snakes & 0 & 2 & 5 & 7 & 3 & 17 \\
\hline Lizards & 0 & 1 & 1 & 0 & 1 & 3 \\
\hline Didelphis marsupialis & 4 & 1 & 1 & 10 & 0 & 16 \\
\hline Cerdocyon thous & 0 & 6 & 4 & 1 & 1 & 12 \\
\hline Tamandua tetradactyla & 0 & 3 & 2 & 2 & 0 & 7 \\
\hline Sylvilagus floridanus & 0 & 2 & 0 & 0 & 0 & 2 \\
\hline Hydrochaerus hydrochaeris & 0 & 0 & 0 & 0 & 3 & 3 \\
\hline Total & 4 & 19 & 17 & 30 & 9 & 79 \\
\hline Route Length $(\mathrm{km})$ & 133 & 88 & 92 & 131 & 128 & 572 \\
\hline Mean Distance Between Roadkills (km) (a) & 166 & 23 & 27 & 22 & 71 & 36 \\
\hline
\end{tabular}

(a) Chi-square $=246.65, p<0.000, d f=4$.

Table II. Roadkills observed during successive passages from Caracas to Mantecal and back (dates of Mantecal to Caracas return trips indicated by asterisks) $(*)$.

\begin{tabular}{|c|c|c|c|c|c|c|}
\hline \multirow{2}{*}{ Animal species } & \multicolumn{5}{|c|}{ Date of observation } & \multirow{2}{*}{ Total } \\
\hline & 27.VI.1978 & 19.VIII.1978 & 24.VIII.1978* & 01.X.1978 & 06.X.1978* & \\
\hline Caiman crocodilus & 4 & 2 & 1 & 7 & 5 & 19 \\
\hline Snakes & 1 & 1 & 1 & 11 & 3 & 17 \\
\hline Lizards & & & & 3 & & 3 \\
\hline Didelphis marsupialis & & 3 & 1 & 7 & 5 & 16 \\
\hline Cerdocyon thous & & 1 & 2 & 5 & 4 & 12 \\
\hline Tamandua tetradactyla & & & & 5 & 2 & 7 \\
\hline Sylvilagus floridanus & & 1 & & & 1 & 1 \\
\hline Hydrochaerus hydrochaeris & & & 3 & & & 3 \\
\hline Total (a) & 5 & 8 & 8 & 38 & 20 & 79 \\
\hline
\end{tabular}


In addition to the counts of carcasses during the five passages described above, some occasional counts were made during other passages between Caracas and Mantecal. In particular, a large number of caiman carcasses was noticed on 3 June, 1978: 10 individuals between Mantecal and San Fernando, 5 between San Fernando de Apure and Calabozo, and two near the reservoir between Calabozo and El Rastro, that is, about 20 km from Calabozo towards Ortiz. We also accidentally struck animals: before sunrise in February 1978, our car killed two capybaras, Hydrochaerus hydrochaeris (Linnaeus, 1766) (Hydrochaeridae) near Mantecal. On another occasion, a bat with a wingspan of about $40 \mathrm{~cm}$ struck our car.

No bird carcasses were found during regular counts, but on other occasions several black vultures had been killed near the carcasses of animals they scavenged. We also saw vultures scavenging on animals killed on the road. On 19 August 1978, we observed several black and turkey vultures scavenging a horse carcass, and also one king vulture, Sarcoramphus papa Linnaeus, 1758 (Cathartidae) - the only observation of this vulture during the study.

\section{DISCUSSION}

The study was conducted during the rainy season, a time when the movements of animals tend to be related to reproduction. During this period, activity increases as animals search for suitable nesting sites and for food, not only for themselves but also for their progeny.

In the llanos section, the annual mean temperature is $26.6^{\circ} \mathrm{C}$. There is less seasonal $\left(3.0^{\circ} \mathrm{C}\right)$ than daily $\left(9.0^{\circ} \mathrm{C}\right)$ variation (CORDERO \& OJASTI 1981). In the rainy season, especially after a tropical shower, the temperature drops, and this may motivate snakes to lie on warm asphalt. This behaviour is known in many regions of the world (Bernardino \& Dalrymple 1992). The highway mortality of snakes in the Sonora Desert of South Arizona, USA, is high during the monsoon-like rainy season, from July to early September. During our study, the largest number of snakes were killed by cars on 1 October, when we passed through several tropical showers (Tab. II). In the Everglades National Park in Florida, USA, the greatest movement of snakes was related to the lower water level at the beginning of the dry season (December-March). This coincided with the highest intensity of motor traffic, and consequently with the highest snake death on the roads. Thus, the rate of snake roadkills was not related to the breeding period (BERNARDINo \& DaLRYMPLE 1992).

Caimans were intensively exploited for skin and meat until 1972. Since 1973, caimans have been protected by law in Venezuela (Pinowski \& Morales 1979). Drainage of llanos and construction of reservoirs (modulos) between Achaguas and Mantecal to store water in the rainy season enhanced a rapid recovery of the caiman population (Rivero Blanco 1974). Female caimans reproduce for the first time at about four years of age, when they are about $125 \mathrm{~cm}$ long. They build nests in August, and they move mainly at night in search of water (STATON \&
Dixon 1977). Most of the caimans killed on the road were young individuals that did not yet reproduce (Tab. III). Caimans inhabiting water bodies do not respond to motor vehicles, even less than $10 \mathrm{~m}$ from the water. Most caimans killed on the road were in the section of roadway crossing gallery forests along the river Apure and its old beds (Tab. I). According to Kushlan (1988), among the causes of unnatural mortality for American crocodiles, Crocodylus acutus Cuvier, 1807 (Crocodylidae), the most common cause of death was being struck by automobiles.

Table III. Length of road-killed reptiles ( $m$ ).

\begin{tabular}{|c|c|c|c|c|c|}
\hline \multirow{2}{*}{ Animal Species } & \multicolumn{5}{|c|}{ Length (m) } \\
\hline & $<0.5$ & $0.5-1.0$ & $1.0-1.5$ & $1.5-2.0$ & $>2.0$ Unknown \\
\hline Caiman crocodilus & 4 & 8 & 2 & & 5 \\
\hline Snakes & 4 & 3 & 4 & 3 & 3 \\
\hline Lizards & 2 & & 1 & & \\
\hline
\end{tabular}

Opossums occur in very different habitats, both natural and anthropogenic, and even in the centres of big cities (CORDERO 2000). Their number increases in the rainy season (CORDERO 2000), that is, during the period of our study. In addition to their normal activity, they may be attracted to roads by the carcasses of killed animals (Bernardino \& Dalrymple 1992, Cordero 2000). Among mammals, opossums were the most frequent roadkills (Tab. I). Also, CoRDERo (2000) found that in the Caracas Metropolitan Area (1200 km² of urban and suburban habitats of the Coastal Cordillera), the opossum is the main species of wild mammal killed on the road. On our observation route, most roadkilled opossums were in the section along gallery forests; also, they were the only roadkills in the Coastal Cordillera zone (Tab. I). Opossums were the most frequent vertebrates killed on the roads in Argentina (Montanelli CÂNDIDo-Jr. et al. 2002) and Brazil (Ribeiro \& Monchiski 1998, CÂndido-Jr. et al. 2002).

The crab-eating fox is a small canine that inhabits open and forested habitats throughout Venezuela (HANDLEY 1976). The crab-eating fox is primarily nocturnal but sometimes can be sighted early in the morning or afternoon (CORDERO \& NASSAR 1999). The main source of killed crab-eating foxes were those struck on the road (BISPAL \& OJASTI 1980, Cordero \& NASSAR 1999), thus it must be a frequent event. We recorded 12 carcasses of these animals, including 6 along non-flooded llanos (Tab. I). Most of them were killed in October (Tab. II). The crab-eating fox was often killed on roads also in Brazil (CÂNDIDO-JR. et al. 2002). Both opossums and crab-eating fox are scavengers and they often patrol roads in search of animals killed by cars (CÂNDIDO-JR. et al. 2002).

Tamandua, Tamandua tetradactyla (Linnaeus, 1758) (Myrmecophagidae) occurs throughout the lowlands and foothills below $500 \mathrm{~m}$ above sea level, most often resting in trees on drier sites. Of 64 individuals recorded by HaNDLEY (1976), 12 were 
struck by automobiles. We found seven carcasses, only in October, in the section crossing non-flooded llanos (Tabs I and II).

The eastern cottontail, Sylvilagus floridanus Allen 1890 (Leporidae) occurs in dry upland sites covered with thorn forests, savannahs, and pastures (HANDlEy 1976). During our study we found only two carcasses of this species, in non-flooded llanos, whereas in Florida (USA) they were rather frequent (0.28 carcasses/km) (CRISTOFFER 1991).

If we make a very conservative assumption that the carcasses of the species we analysed remained for two days on the road, then motor vehicles would strike 350 caimans in the rainy season alone, from May through October (184 days divided by 2 (persistence of carcasses) $=92 \times 3.8$ (mean number of caimans struck per day). Similar calculations for other species yield 313 snakes and lizards, 294 opossums, 220 crab-eating foxes, 129 tamanduas, 55 capybaras, and 37 eastern cottontails. It is difficult to estimate what proportion of the total population was killed by vehicles.

In Venezuela, spectacled caimans are under permanent management programs, since 1983 and capybara since 1968. Opossums and eastern cottontails are included in the sport hunting season and allowed to be hunted in their respective season and bag limits. Crab-eating foxes and tamanduas are not under special legal protection, but each species that is not included in commercial or sport management programs is not allowed to be hunted in any way (RICARDO BABARRO - Ministry of the Environment and Natural Resources of Venezuela, information by letter). In our study area, very rare animal species were not killed on the road. In Brazil, animals threatened with extinction, such as jaguar, Felis onca Linnaeus, 1758 (Felidae), ocelot, Felis pardalis Linnaeus, 1758 (Felidae), marsh deer, Blastocerus dichotomus Illiger, 1815 (Cervidae), neotropical otter, Lontra longicaudis Olfers, 1818 (Mustelidae), maned wolf, Chrysocyon brachyurus Illiger, 1815 (Canidae) (Ministério do MeIo AMBIENTE 2003)were killed by motor vehicles (Fischer 2002). It should be emphasized that our study was conducted late in the 1970s, when motor traffic was considerably less intense.

\section{ACKNOWLEDGEMENTS}

We are very indebted to Jose Flavio Cândido-Jr., Liliana Forneris, Zbigniew Glowacinski, Paulo A. M. Marques, Fernando C. Straube and Teresa Tomek for procurement of literature and to Ginny Lagather for correction final English version. The materials to above paper we gathered during our stay in the Institute of Tropical Zoology Central University of Venezuela, Caracas.

\section{REFERENCES}

BENNET, A.F. 1991. Roads, roadsides and wildlife conservation: a review, p. 99-118. In: D.A. SAunders \& R.J. Hobbs (Eds). Nature Conservation 2: The Role of Corridors. Chipping Norton, Beatty and Sons, XII+442p.
Bencke, G.A. \& C.S.C. Bencke. 1999. The potential importance of road deaths as cause of mortality for large forest owls in southern Brasil. Cotinga, Bedfordshire, 11: 79-80.

Bernardino Jr., F.S. \& G.H. Dalrymple. 1992. Seasonal activity and road mortality of the snakes of the Pa-hay-okee wetlands of Everglades National Park, USA. Biological Conservation, Barking, 62: 71-75.

Berezovikov, N.N. 1995. [On mortality of vertebrates on the highways]. Selevinia, Almaty, 3: 82-85 [in Russian].

Bisbal, F. \& J. OJASTi. 1980. Food niche of the fox Cerdocyon thous (Mammalia, Carnivora). Acta Biologica Venezuelica, Caracas, 10: 469-496.

BRoekhuysen, G. 1965. An analysis of bird casualties on the roads in South Western Cape Province, South Africa. L'Oiseau et Revue Française d'Ornithologie, Paris, 35: 35-51.

CÂndido-Jr., J.F.; V.P. Margarido, J.L. Pegoraro, A.R.D’Amico, W.D. Madeira, V.C. Casale \& L. Andrade 2002. Animais atropelados na rodovia que margeia o Parque Nacional do Iguaçu, Paraná, Brasil, e seu aproveitamento para estudos da biologia da conservação. In: Anais do III Congresso Brasileiro de Unidades de Conservação, p. 553-562.

Coleman, J.S. \& J.D. Fraser. 1989. Habitat use and home ranges of Black and Turkey Vultures. Journal of Wildlife Management, Bethesda, 53: 782-792.

Cordero, R.G. 2000 The biology of the opossum (Didelphis marsupialis) in urbanized enviroments from Northern Venezuela. Acta Biologica Venezuelica, Caracas, 20 (2): 13-28.

Cordero, G. \& J. Nassar. 1999. Ecological data on Cerdocyon thous in Barlovento region, estate of Miranda, Venezuela. Acta Biologica Venezuelica, Caracas, 19 (4): 21-26.

Cordero, G.A. \& J. Ojasti. 1981. Comparison of capybara populations of open and forested habitats. Journal of Wildlife Management, Bethesda, 45: 267-271.

Cristoffer, C. 1991. Road mortalities of Northern Florida vertebrates. Florida Scientist, Orlando, 54: 65-68.

Dhindsa, M.S.; J.S. SAndhu, P.S. SAndhu \& H.S. Toor. 1988. Roadside birds in Punjab (India): Relation to mortality from vehicles. Environmental Conservation, Lausanne, 15: 303310.

Dickerson, L.M. 1939. The problem of wildlife destruction by automobile traffic. Journal of Wildlife Management, Bethesda, 3: 104-116.

Drews, C. 1995. Road kills of animals by public traffic in Micumi National Park, Tanzania, with notes on baboon mortality. African Journal of Ecology, Oxford, 33: 89-100.

Fisher, W.A. 2002. Efeitos da BR-262 na mortalidade de vertebrados silvestres: síntense naturalística para a conservação da região do Pantanal, MS. Available from World Wide Web: http://www.ufms.br/pagbio/panta/wagner.pdf, 15/VII/ 2002.

Forman, R. T. T., 1995. Land Mozaics: The Ecology of Landscapes and Regions. Cambridge, Cambridge University Press, $\mathrm{XX}+632 \mathrm{p}$.

Revista Brasileira de Zoologia 22 (1): 191-196, março 2005 
Forman, R.T.T. \& L.E. AleXANDER. 1998. Roads and their major ecological effects. Annual Review of Ecology and Systematics, Palo Alto, 29: 207-231.

Gottdenker, N.; R.B. Wallace \& H. Gómez. 2001. La importancia de los atropellos para la ecología y coservación: Dinomys branickii un ejemplo de Bolivia. Ecología en Bolivia, La Paz, 35: 61-67.

Handley, C.S. 1976. Mammal of the Smithsonian Venezuelan Project. Brigham Young University Science Bulletin, Biological Series, Provo, 20: 1-91.

IRISOV, E.A. 1990. [The bird mortality on roads in Altai Krai (territory)], p. 88-90. In: T.A. TERechina (Ed.). Biotzenozy Altaiskogo kraya i vlivanie na nikh antropogennykh vozdeistvity. Barnaul, 149p. [in Russian].

JACKSON H.D. 2002. A review of Afrotropical nightjar mortality, mainly road kills. Ostrich, Pretoria, 73: 147-161.

KNobloch, W. 1939. Death on the highway. Journal of Mammalogy, Baltimore, 20: 508-509.

Kushlan, J.A. 1988. Conservation and management of the American Crocodile. Environmental Management, New York, 12: 777-790.

LEwIS, A.D. 1989. Road kills and others records of mainly smaller mammals from Kenya: data for a Kenyan mammal atlas. East African Natural History Society Bulletin, Nairobi, 19: 20-22.

Marrero, L. 1978. Atlas geografico y economico Venezuela visualisada. Caracas, Cultural Venezolana, 241p.

Ministério do Meio Ambiente. 2003. Lista nacional das espécies da fauna brasileira ameaçadas de extinção. Available from World Wide Web: http://www.mma.gov.br/post/sbf/ fauna/lista.html, 1/VIII/2003.

Novelli, R.; E. Takase \& V. Castro. 1988. Study of birds killed by collision with vehicles in a stretch of highway BR-471 between Quinta and Taim, Rio Grande do Sul. Revista Brasileira de Zoologia, Rio de Janeiro, 5: 441-454.

Pinowski, J. \& L.G. Morales. 1979. [The caimans of the Llanos of Venezuela]. Wszechswiat, Kraków, 4 (2148): 74-76 [in Polish].

Ribeiro, S. \& A.S. Monchiski. 1998. Animais atropelados nas rodoVIAS DO Estado do Rio Grande do Sul, Brasil. III ${ }^{\circ}$ Congresso Ibero-Americano de Unidades Ambientais no Setor de Transportes. Available from World Wide Web: http://
200.180.3.8/iiiencontro/autores/P25/principal.htm, 15/ $\mathrm{VII} / 2002$.

Rivero Blanco, C. 1974. Habitos reproductives de la baba en los Llanos de Venezuela. Natura, Caracas, 52: 25-29.

Rodda, G.H. 1990. Highway madness revisited: Roadkilled Iguana iguana in the Llanos of Venezuela. Journal of Herpetology, Houston, 24: 209-211.

Siegfried, W.R. 1965. A survey of wildlife mortality on roads in the Cape Province, p. 5-6. In: Department of Natural Conservation, Investigation Report no. 6, Provincial Administration Cape of Good Hope, Cape Town.

Siegrried, W.R. 1966. Casualties among birds along a selected road in Stellenbosch. Ostrich, Pretoria, 37: 146-148.

Sprague, J.M. 1939. Notes on mammal mortality on highway. Journal of Mammalogy, Baltimore, 20: 110-111.

SPRUnT JR., A. 1937. Turkey vultures killed by automobiles. Auk, Lancaster, 54: 383-384.

Staton, M.A. \& J.R. Dixon. 1977. Breeding biology of Spectacled Caiman, Caiman crocodilus crocodilus in Venezuelan Llanos, p. 1-21. In: Wildlife Research Report 5, Washington, United States Department of the Interior, Fish and Wildlife Service.

STONER, D. 1925. The toll of the automobile. Science, Lancaster, 61: 56-57.

STONER, D. 1935. Highway mortality among mammals. Science, Lancaster, 81: 401-402.

Takeuchi, M. \& M. Koganezawa. 1994. Age distribution, sex ratio and mortality of the Red Fox Vulpes vulpes in Tochigi, Central Japan: an estimation using a museum collection. Researches on Population Ecology, Kyoto, 36: 37-43.

Trombulak, S.C. \& C.A. Frissell. 2000. Review of ecological effects of roads on terrestrial and aquatic communities. Conservation Biology, Boston, 14: 18-30.

Valladares Padua, C.; L. Cullen Jr. \& S. Padua. 1995. A pole bridge to avoid primate roadkills. Neotropical Primate, Belo Horizonte, Minas Gerais, 3: 13-15.

VIEIRA, E.M. 1996. Highway mortality of mammals in central Brazil. Ciência e Cultura. Journal of the Brazilian Association for the Advancement of Science, São Paulo, 48 (4): 270-271.

Wallace, M.P. \& S.A. Temple. 1987. Competitive interactions within and between species in a guild of avian scavenger. Auk, Columbus, 104: 290-295.

Received in 20.IV.2004; accepted in 17.II.2005. 